\title{
The Effect of Leadership, Organization Culture, and Work Motivation on Job Performance of Principal of State Primary School in South Tangerang Banten
}

\author{
Ade Mujhiyat ${ }^{1}$, Thamrin Abdullah ${ }^{2}$, Maruf Akbar ${ }^{3}$ \\ \{mujhiyat@yahoo.com ${ }^{1}$, thamrin.abdullah@yahoo.co.id ${ }^{2}$, marufakbar_unj@yahoo.co.id ${ }^{3}$ \} \\ 1,2,3 Universitas Negeri Jakarta, Indonesia
}

\begin{abstract}
The objective of the research is to obtain information about the influence of leadership, organization culture and motivation on the job performance of state primary school principals in South Tangerang, Banten. The research made use of a survey method comprising of path analysis and testing hypothesis. Seventy principals were randomly selected from a total of one hundred fifty nine using Slovin formula. The result of the study reveals that there is direct effect of leadership, organization culture, and motivation on job performance, as well as leadership, and organization culture on motivation. Therefore, the principals' job performance can be enhanced by leadership, organization culture and motivation.
\end{abstract}

Keywords: Leadership, organization culture, motivation, and job performance

\section{Introduction}

A school principal is an educationist or a professional manager who has a significant influence in improving the quality of education and in determining the educational objectives of teachers and students. The curriculum, and teaching methods, is incomplete without the proper guidance of the principal as the key to success lies in them. In order for a principal to effectively and efficiently carry out his/her duties effectively, he/she must be good at managing and utilizing available resources, such as humans (man), funds (money), facilities (material), and time. Furthermore, the principal will excel tremendously by utilizing four managerial skills functions, namely: planning, organizing, leadership, and supervision. Performance can be described as an employee's behaviour in fulfilling a given organizational goal.. Various internal and external factors tend to affect the performance of a principal. This study aims to prove the effects of superior leadership, organizational culture and work motivation in the performance of Tangerang Elementary School principals in Banten.

\subsection{Performance}


According to Michael Armstrong [1]. "performance is simply defined as the terms used to achieve quantified objectives. It isn't only what people accomplish but how they get it done ". Furthermore Brumbach, [2] defines it as a behaviour that emanates from a performer and transformed into skills to achieve an organizations set goal..

Stephen P. Robbins and Mary Coulter [3] explained that performance is the end result of an activity. Debra L. Nelson and James Campbell Quick [4] beams that finance enhances performance. John P. Campbell and Brenton M. Wiernik [5] added that, "individual job performance should be defined as actions taken by individuals to contribute to an organization's set goals. Richard L. Daft (2012: 10) defined performance as an organization's ability to achieve goals efficiently and effectively. According to Colquitt, LePine and Wesson [6] "job performance is defined as the value of the set of employees behaviours that contribute, either positively or negatively, to the achievement of its organizational goal ". Thus it can be synthesized that performance is the result of one's working ability in carrying out set objectives that are his/her responsibility as a way of achieving organizational goals.

\subsection{Leadership}

Stephen P. Robbins [3] defines leadership as the ability to influence a group of people toward achieving set goals". Similarly, Robbins and Coulter [4] emphasized that leadership is a process of leading and prompting a group to achieve its goal. Stoner, Freeman, and Gilbert [5] defined it as the process of directing and influencing task-related activities of a group of people. This concept implies that a leader must optimally ensure that his/her subordinates are willing to work together and productively to achieve the organizations set objectives.

According to Colquitt, LePine and Wesson [4] "leadership is the use of power and authority to direct the activities of followers toward goal achievement". Furthermore John M. Ivancevich, Robert Konopaske, and Michael T. Matteson [6] explained leadership as the process of influencing others to facilitate the attainment of organizational relevant goals. Furthermore, James L. Gibson, John M. Ivancevich, James H. Donnelly, Jr., and Robert Konopaske [7] defined it as the act of guiding and inspiring individuals to fulfil some purpose. Krietner and Kinicki [2] opined that leadership is process whereby the individual prompts others to achieve a common goal. Furthermore, Robert Tannenbaum, Irving R. Weschler, Fred Massarik [4] definesleadership as interpersonal power exercised in a situation and directed through the communication process, toward the attainment of specified goal/s". According to Robert N. Lussier and Christopher F. Achua [5], "leadership is the influencing process of leaders and followers to achieve organizational objectives through change". Leadership is a process of mutual influence between leaders and followers in achieving organizational goals through change.

Thus it can be synthesized that superior leadership is an activity carried out by influencing, mobilizing and equipping others to work in achieving organizational goals through interaction, communication and cooperation.

\subsection{Organizational Culture}

Organizational culture as stated by Robbins and Judge (2009: 585) is a system whereby members of an organization shared meaningful ideas that distinguishes it from other organizations. 
According to James L. Gibson, John M. Ivancevich, James H. Donnelly, Jr., and Robert Konopaske (2013: 31), "organizational culture is what employees perceive and how this perception creates a pattern of beliefs, values, and expectations". Furthermore, they quoted the opinion of Edgar Schein (3013: 31) on the definition of culture, in which theydefined culture as "A pattern of basic assumptions-invented, discovered, or developed by a given group as it learns to cope with the problems of external adaptation and internal integration-that has worked well enough to be considered valid and, therefore, to be taught to new members as the correct way to perceive, think, and feel in relation to those problems."James L. Gibson, John M. Ivancevich , James H. Donnelly, Jr., and Robert Konopaske (2013: 31) beams that, the Schein definition points out that culture involves assumptions, adaptations, perceptions, and learning".

Furthermore Jason A. Colquitt, Jeffery, A. Lepine, and Michael J. Wesson, (2015: 534) defined, organization culture as the shared social knowledge with respect to the rules, norms, and values that shapes the attitudes and behaviours of its employees. Similarly McShane and Von Glinow (2008: 460) explained it as the basic pattern of shared values and assumptions governing the way employees within an organization think and act on problems and opportunities.

According to John R. Schermerhorn, Jr., James G. Hunt and Richard N. Osborn (2002: 43), "Organizational or corporate culture is the system of shared actions, values, and beliefs that develops within an organization and guides the behaviour of its members". Marios I. Katsioloudes (2006: 122)defines it as, "The philosophies, ideologies, values, assumptions, beliefs, expectations, attitudes, and norms that knit an organization together ".

John W. Newstrom (2007: 87), Robert E. Stevens \& David L. Loudon (2008: 93), and Robert Kreitner and Angelo Kinicki (2010: 64) opined that"organizational culture is the values, norms, and attitudes of the people who make up an organization". Thus it can be synthesized that organizational culture is a system of values, norms, and beliefs that exist within the organization which becomes a behaviour pattern of "collective personality." It is formed from the process of interaction, perspective, comprehension, and reactions that guide organizational members to achieve common goals.

\subsection{Work Motivation}

Steven L. McShane and Mary Ann Von Glinow [8] defined motivation as "forces within a person that affects the direction, intensity, and persistence of voluntary behaviour". Furthermore James L. Gibson, John M. Ivancevich, James H. Donnelly, Jr., and Robert Konopaske [8] described it as"the forces acting on an employee that initiates and direct behaviour". According to Kreitner and Kinicki [9],"motivation represents those psychological processes that cause the arousal, direction, and persistence of voluntary actions that directed towards a goal".

Colquitt, LePine, and Wesson [10]. described it as a set of energetic forces that originates within and outside an employee that initiates work-related effort." Stephen P. Robbins and Mary Coulter [12] explained motivation as the processes by which people are energized, directed, and sustained toward attaining an objective. John M. Ivancevich, Robert Konopaske, and Michael T. Matteson [11] explained that motivation is made up three distinct components: direction, intensity, and persistence."

According to Robert E. Stevens \& David L. Loudon [14]. "motivation is the process of arousing action, sustaining the activity in progress, and regulating the pattern of activity". 
Furthermore, Bateman and Snell [16] attribute it to the forces that energize, direct, and sustain a person's efforts.

Based on various opinions regarding the above understanding, there are three basic components of motivation, namely those that work hard, stay on their job, and those that directs their behaviour towards achieving the appropriate goals. In general, those definitions contain three general aspects of work motivation, namely business, determination, and direction.

Thus it can be synthesized that work motivation is an impulse in someone who raises an effort to direct behaviour in carrying out activities to achieve goals and results through effective and efficient work activities.

\section{Research Methods}

This research was conducted on principals in South Tangerang City Elementary Schools located in Banten. A survey method using a quantitative approach was used to describe the causal relationship using path analysis. The population study was 159 school principals out of which 70 were randomly selected. Data was collected using a questionnaire with a Likert scale consisting of five scales in the form of items that represent the variables to be analysed. The results of the trials of each variable are based on the calculation, the validity of the performance instruments with $\mathrm{n}=$ 30 , of the 35 items of statements. 3 items were invalid (drop) with the magnitude of the reliability coefficient of $r=0.9760$. The validity of superior leadership instruments with $n=30$, out of 30 items, resulted in 3 invalid items with reliability coefficient of $r=0.8942$. While the validity of organizational culture instruments with $\mathrm{n}=30$, out of 30 items, gave 2 invalid (drop) items with a coefficient of $r=0.9340$ and 0.9278 . Data analysis was performed with descriptive and inferential statistics.

\section{Results and Conclusions}

The results of the first hypothesis testing indicates that there is a positive direct effect of superior leadership on the performance of principals with a path coefficient of 0.300 and a correlation coefficient of 0,473 . This shows that an increase in leadership, results in an increase in the performance of the principal of South Tangerang Elementary Schools. The results of testing the second hypothesis show that there is a positive direct effect of organizational culture on the performance of principals with a path and correlation coefficients of 0.294 and 0.466 respectively. This shows that an increase in organizational culture resulted in an increase in the performance of the principal. The results of the third hypothesis testing show that there is a positive direct effect of work motivation on the performance of the principal with a path coefficient of 0.291 and a correlation coefficient of 0.497 . This shows an increase in work motivation resulting in an increase in the performance of the. The results of the fourth hypothesis testing show that there is a positive direct effect of superior leadership on the work motivation of the principal with a path coefficient of 0.285 and a correlation coefficient of 0.351 . This shows an increase in a leadership resulting in 
an increase in the work motivation of the principal of the South Tangerang City Elementary School. Meanwhile, the calculation of the influence of organizational culture on work motivation shows that organizational culture has a positive direct effect on work motivation with a path coefficient of 0.275 and a correlation coefficient of 0.343 . This means that the increase in organizational culture has resulted in an increase in the work motivation of principals in South Tangerang City Elementary School.

\section{References}

[1] Armstrong, Michael.: Performance management: key strategies and practical guidelines, 3rd ed, London: Kogan-Page (2006)

[2] Bateman, Thomas S. dan Snell, Scott A.: Management Leading \& Collaborating in a Competitive World. New York: McGraw-Hill (2013)

[3] Campbell, John P. and Wiernik, Brenton M.: The Modeling and Assessment of Work Performance. Minneapolis, Minnesota: Department of Psychology, University of Minnesota, (2015)

[4] Colquitt, Jason A., Jeffery, A. Lepine, Wesson, Michael J. Organizational Behavior: Improving performance and commitment in the workplace. New York: McGraw-Hill/Irwin, 2015.

[5] Daft, Richard L.: Management. USA: South-Western (2012)

[6] Dubrin, Andrew J.: Essential of Management. Cincinati,Ohio:South Western Publishing,Co (2012)

[7] Gibson, James L., Ivancevich, John M., Donnelly, James H., and Konopaske, Robert.: Organizations: Behavior, Structure, Processes. 14th ed. New York: McGraw-Hill Companies, Inc. (2012)

[8] Ivancevich, John M., Konopaske, Robert, dan Matteson, Michael T.: Organizational Behavior and Management. New York: McGraw-Hill Irwin (2008)

[9] Katsioloudes, Marios I., Strategic management : global cultural perspectives for profit and non profit organizations. New York: Elsevier Inc. (2006)

[10] Kondalkar, V.G., Organizational Behavior. New Delhi: New Age International (P) Limited Publisher (2007)

[11] Kreitner, Robert and Kinicki, Angelo, Organizational Behavior, Ninth Edition. New York: McGraw- Hill Irwin (2010)

[12] Lussier, Robert N. and Achua, Christopher F., Effective Leadership, 5th Edition. Canada: South-Western Cengage Learning (2013)

[13] McShane, Steven L. dan Glinow, Mary Ann Von, Organizational Behavior, Fourth Edition. New York: McGraw-Hill Irwin (2008)

[14] Nelson, Debra L. dan Quick, James Campbell, Organizational Behavior : Foundations, Realities \& Challenges. USA : Thomson (2006)

[15] Newstrom, John W., Organization Behavior : Human Behavior at work. New York: McGraw-Hill (2002)

[16] Robbins, Stephen P. dan Coulter, Mary, Management, England: Pearson Education Limited (2012) 
[17] Robbins, Stephen P. and Judge, Timothy.: Organizational Behavior, 13th edition. New Jersey: Prentice Hall Int'l, Inc (2013)

[18] Robbins, Stephen P.: Organizational Behavior: Concept, Controvercies, Aplication. New Jersey: Prentice-Hall International, Inc. (1990)

[19] Schermerhorn, Jr., John R., Hunt, James G. dan Osborn, Richard N.: Principles of Organization Behavior. USA: John Wiley \& Sons, Inc., 7th Edition (2002)

[20] Stevens, Robert E. \& Loudon, David L.: Organizational Behavior. New York: Best Business Books (2002)

[21] Stoner, James A. F., Freeman, R. Edward, Gilbert. JR., Daniel R.: Management. 6th Ed. New Jersey: Prentice Hall, Inc (1995)

[22] Tilaar, H.A.R.: Perubahan Sosial dan Pendidikan: Pengantar Pedagogik Transformatif Untuk Indonesia. Jakarta: Grasindo (2002)

[23] Tannenbaum, Robert, Weschler, Irving R., and Massarik, Fred.: Leadership and Organization A Behavioral Science Approach. London and New York: Routledge (2013) 